\title{
Microautologous Fat Transplantation (MAFT) sebagai Rekonstruksi Lanjutan pada Kasus Deformitas Maksilofasial Pasca Trauma
}

\author{
Ardea Ramadhanti Perdanakusuma ${ }^{\mathrm{a}}$, Ariani Primawatia, Budiman ${ }^{\mathrm{b}}$ (iD \\ a Pro Aesthetic Clinic, Klinik Bedah Plastik dan Rekonstruksi \\ b Rumah Sakit Pusat Angkatan Darat Gatot Soebroto \\ *Corresponding author: Ardea Ramadhanti Perdanakusuma - Pro Aesthetic Clinic, Klinik Bedah Plastik dan Rekonstruksi
}

\section{ARTICLE INFO}

Kata Kunci:

MAFT Gun, Fat Transfer, fraktur maksilofasial, wajah asimetri

*Corresponding author:

Ardea Ramadhanti

Perdanakusuma

Email address:

ardearamadhanti@yahoo.com

History:

Received: 5 Oktober 2021

Accepted: 15 November 2021

\section{ABSTRAK}

Latar Belakang: Teknik Microautologous Fat Transplantation (MAFT) merupakan sebuah metode yang relatif baru untuk memindahkan lemak dari lokasi tubuh tertentu ke lokasi tubuh yang diinginkan dengan suatu alat khusus. Teknik transfer lemak sebenarnya sudah dilakukan sejak tahun 1893 namun terkendala dengan masih banyaknya lemak yang diresorpsi sehingga memerlukan beberapa kali tindakan ulangan. Teknik Microatutologus Fat Transplantation menggunakan MAFT Gun pertama kali dilakukan oleh Lin et al. pada tahun 2006. Teknik ini telah menunjukkan hasil yang baik dalam bidang estetik maupun rekonstruksi menggantikan teknik dermofat graft yang bersifat lebih invasive. Deformitas pada wajah akibat dari hilangnya sejumlah volume lemak dapat diatasi dengan MAFT Gun yang bersifat minimal invasif. Pada tulisan ini dilaporkan satu kasus penanganan deformitas maksilofasial pasca reposisi dan fiksasi fraktur tulang wajah dengan Microautologous Fat Transplantation sebagai salah satu modalitas.

Pasien dan Metode: Jaringan lemak diambil dengan spuit 60 cc tekanan negatif kemudian dilakukan sentrifugasi dengan kecepatan 3000 rpm selama 10 menit untuk memisahkan komponen lemak dan plasma. Lapisan lemak murni selanjutnya ditransplantasikan pada area wajah menggunakan MAFT Gun di bawah mata $3.5 \mathrm{ml}$, pipi $20.5 \mathrm{ml}$, dagu $3 \mathrm{ml}$, dan pelipis $1 \mathrm{ml}$.

Hasil: Lama tindakan 2 jam 30 menit, prosedur anestesi sedasi sedang dan blok nervus infraorbitalis, nervus mentalis, dan nervus supraorbitalis, dan nervus supratrochealis ipsilateral. Deformitas dapat teratasi, longterm follow up 3 bulan pasca operasi tidak banyak jaringan lemak yang diresorpsi, sehingga penampilan masih baik.

Kesimpulan: Teknik MAFT Gun merupakan prosedur yang efektif untuk memperbaiki kontur wajah, peremajaan wajah, memperbaiki area yang cekung, dan mengembalikan volume termasuk mengoreksi deformitas wajah akibat fraktur maksilofasial pasca reposisi fraktur maksilofasial yang kurang sempurna. Prosedur yang dilakukan relatif tidak invasif. Jaringan lemak dapat diambil dari berbagai area tubuh yang memiliki jaringan lemak berlebih. Menggunakan MAFT Gun yang telah tersertifikasi, proses transfer lemak dapat dilakukan secara akurat dan konsisten. Hasil MAFT cukup memuaskan bagi pasien, sehingga memungkinkan prosedur MAFT menjadi alternatif solusi untuk mengoreksi deformitas maksilofasial pasca reposisi dan fiksasi yang mungkin hanya memerlukan tindakan touch up satu sampai dua kali saja.

\section{LATAR BELAKANG}

Wajah merupakan bagian dari tubuh manusia yang memegang daya tarik dalam interaksi sosial. Salah satu faktor yang menjadi permasalahan dari tampilan adalah adanya asimetri wajah. Solusi yang potensial untuk memperbaiki yaitu dengan Microautologous 
Fat Transplantation (MAFT) yang dikenal sebagai teknik lipofilling atau pencangkokan lemak. Teknik ini dianggap sebagai teknik unggul yang berpotensi dalam mengoreksi deformitas kontur jaringan lunak dan defisit volume di hampir semua bagian tubuh. Pada teknik ini dilakukan pengambilan lemak dari bagian tubuh lain dengan kelebihan lemak kemudian disuntikkan ke bagian yang cekung untuk menambah volume. Pengaplikasian teknik ini dapat digunakan untuk mengoreksi kerutan atau keriput di wajah, menambah volume di area cekung atau depres, mengisi kontur wajah yang tidak beraturan yang dapat tahan lama dan relatif permanen. Pemanfaatannya pada perbaikan wajah memerlukan perhatian khusus dengan ketepatan karena dapat diperoleh melalu titrasi dan injeksi lemak pasien sendiri dengan pendekatan minimal invasif.

Dalam 2 dekade terakhir ini telah banyak digunakan filler jaringan lunak pada fosa temporal untuk mengisi volume. Teknik ini juga dilakukan pada dahi untuk kontur estetika. Namun komplikasi juga terjadi pasca non-autologous filler (paraffin, silikon cair, asam hialuronat). Lee et al. melaporkan terjadi beberapa komplikasi yang sering pasca injeksi non-autologous filler yaitu reaksi alergi (25\%), migrasi bahan pengisi (12.5\%), nekrosis injeksi dan emboli (25\%), dan granuloma benda asing (37.5\%). ${ }^{1,2}$

Grafting lemak pertama kali dikenalkan oleh seorang dokter bedah asal Jerman, Gustav Neuber, pada tahun 1893 kemudian menjadi prosedur umum karena hasil yang menjanjikan, volume yang memadai, dan tidak ada reaksi penolakan. Hal ini telah menjadi perhatian dan dapat diterima secara klinis. Pada tahun 2006 Lin et al. mempromosikan Teknik MAFT Gun dan kemampuannya dalam peremajaan wajah. ${ }^{1,2}$

Adanya deformitas pada wajah pasca trauma merugikan secara estetika dan kehidupan sosial. Selain itu deformitas juga dapat timbul karena perawatan yang tidak memadai atau tidak diterima setelah terjadi trauma. Pasien yang menerima pengobatan secara cepat dan tepat, juga dapat mengalami deformitas sekunder pada wajah karena adanya proses penyembuhan yang tidak terduga. Hal ini menjadi tantangan para klinisi untuk dapat memperbaiki deformitas wajah secara sekunder. ${ }^{2}$

Fraktur Zygomaticomaxillary Complex (ZMC) pasca kecelakaan lalu lintas menjadi permasalahan tersendiri karena fraktur terjadi pada penopang besar kerangka midfasial yang akan mempengaruhi penampilan struktur, fungsional, dan estetika kerangka wajah. Fraktur ini juga dikenal sebagai fraktur tripod, tetrapod, quadripod, fraktur trimalar atau fraktur malar. ${ }^{3}$

Tatalaksana pada setiap jenis fraktur ini akan berbeda berdasarkan stabilitasnya. Fraktur stabil akan dilakukan reduksi kemudian diikuti dengan fiksasi menggunakan plate dan screw pada satu titik. Sedangkan fraktur tidak stabil akan mendapat fiksasi pada tiga titik. Namun pada umum fraktur akan difiksasi pada dua titik. ${ }^{3}$

Pada fraktur ZMC yang menjadi indikasi untuk dilakukan operasi adalah adanya perpindahan dan rotasi, serta perpindahan tersebut harus mendapat pembedahan. Pembedahan tersebut dilakukan dengan pendekatan temuan pemeriksaan klinis dan radiologi. ${ }^{3}$ Kontur dinding orbital yang hilang diperbaiki dengan mengembalikan volume orbital sebelumnya. ${ }^{4,5}$

Manajemen fraktur ZMC menjadi tantangan terutama dalam operasi bedah plastik. Apabila tidak dilakukan reduksi dalam waktu dan teknik yang tepat wajah akan menjadi asimetri. ${ }^{3}$ Kesalahan sedikit dalam penempatan potongan fraktur zigomatik dapat menimbulkan wajah tampak asimetri tanpa adanya gangguan fungsional. Kasus asimetris pasca reposisi dan fiksasi pada umumnya akibat patah tulang dinding anterior sinus maksilaris yang tidak tereposisi dengan adekuat. 
Atrofi otot-otot wajah juga menyebabkan wajah asimetri. ${ }^{5}$ Para ahli bedah plastik telah mencari berbagai alternatif menemukan bahan untuk mengisi jaringan lunak yang cekung, baik dengan implan padat maupun filler sintesis yang aman. Pemilihan lemak autologous merupakan pilihan yang aman. Graft lemak dalam jumlah besar tentu saja akan diserap oleh karena imbibisi vaskuler dari resipien bed tidak sampai ke bagian tengah dari volume lemak tersebut, sehingga untuk pertama kali dipilih dermofat graft. Dermofat graft merupakan graft yang terdiri dari kulit dan lemak subkutis, yang mana bagian kulitnya dilakukan deepitelisasi.

Tujuan transfer lemak adalah untuk mengisi area yang cekung pada bagian tertentu dengan memindahkan sejumlah volume lemak. Selain itu jumlah jaringan lunak lemak subkutan juga dapat bertambah dengan metode ini. Keberhasilan lipotransfer dalam mengisi kecacatan pasca trauma dan menjaga restorasi simetri wajah telah banyak ditampilkan dalam beberapa literatur. 2,6,7

Besarnya dampak fraktur orbitozygomatik terhadap gangguan fungsional dan estetika, seperti diplopia dan wajah asimetri dapat dikoreksi dengan tindakan reposisi komponen-komponen tulang yang mengalami fraktur, namun tidak sedikit kasus yang masih menyisakan deformitas terutama pada kasus yang neglected akibat timing operasi yang terlalu lambat. ${ }^{8}$

Timing operasi yang dilakukan terlalu lambat menyebabkan komponen tulang sudah mengalami healing dan perlengketan, sehingga harus dilakukan refrakturisasi dahulu sebelum dilakukan reposisi, menurut pengalaman sangat sulit melakukan reposisi dinding anterior sinus yang sudah melekat pada dinding posterior oleh karena tulang tersebut sangat tipis. Pemilihan transfer lemak sebagai salah satu modalitas untuk mengatasi masalah ini dapat dijadikan salah satu pilihan dibandingkan dengan pemanfaatan implan yang bersifat invasif. Banyak literatur yang menunjukkan keberhasilan transfer lemak dalam memperbaiki asimetri wajah.

\section{PASIEN DAN METODE}

\section{Demografi Pasien}

Wanita, 39 tahun datang dengan keluhan pipi cekung dan bibir asimetris. Sebelumnya pasien mengalami kecelakaan sepeda motor pada bulan September 2020 yang menyebabkan patah tulang pipi sisi kanan dan luka robek pada wajah. Pasien sudah menjalani operasi oleh dokter spesialis bedah plastik rekonstruksi dan estetik di RS Siloam dengan diagnosis fraktur Zygomaticomaxillary Complex (ZMC) kanan dan luka robek pipi kanan dilakukan reposisi dengan miniplate, screw, dan rekontruksi penutupan luka.

Pada pemeriksaan fisik didapatkan keadaan umum tampak baik, tanda-tanda vital normal, pada bagian wajah dan bibir terlihat asimetris yang disebabkan kehilangan sebagian jaringan lunak. Evaluasi pada nervus fasialis masih tampak gerakan pada otot ipsilateral, kesan atrofi otot wajah dengan nervus fasialis masih intak, ditemukan parut berbentuk segitiga (mengalami trapped door deformity).

Pasien datang dengan membawa hasil CT-Scan tulang wajah non-contrast tanggal 17 Maret 2021. Hasil bacaan sebagai berikut: "Didapatkan 1) Fiksasi interna berupa miniplate dan screw di processus frontalis os zygomaticus kanan pada fraktur komplit os zygomaticus kanan dengan kedudukan fiksasi baik, tidak tampak loosening. Tampak displacement fragmen distal fraktur ke posterior. 2) Fiksasi interna berupa miniplate and screw di dinding anterior sinus maksilaris kanan hingga os maxilla dan processus temporalis os zygomaticus kanan dengan kedudukan baik, tidak tampak loosening. Tampak defek dinding anterolateral sinus maksilaris kanan dan garis fraktur multipel di processus zygomaticus kanan dengan 
kedudukan relatif segaris sesuai alignment anatomis."

Berdasarkan pemeriksaan tersebut pasien di diagnosis asimetris wajah dan bibir pasca reposisi fraktur ZMC kanan dengan mini plate, screw dan penutupan luka dengan flap lokal. Dilakukan operasi rekonstruksi komisura dengan static sling prolene ke arah mastoid dan Microautologous Fat Tranplantation (MAFT).

\section{Preoperasi}

Sebelum tindakan dimulai, pasien mendapat informasi secara lisan mengenai tindakan yang akan dilakukan dan diminta untuk memberikan persetujuan tertulis setelah mendapat informasi. Evaluasi klinis dan radiografi dari lesi dilakukan pada kegiatan preoperasi.

\section{Anestesi}

Pasien berada dalam anestesi sedasi sedang melalui intravena selama prosedur MAFT. Jaringan lemak diambil dari paha bagian medial. Area tersebut diinfiltrasi terlebih dahulu dengan larutan tumescent dengan rasio $10 \mathrm{ml}$ lidokain $2 \%(20 \mathrm{mg} / \mathrm{ml})$ : $30 \mathrm{ml}$ larutan ringer laktat: $0.2 \mathrm{ml}$ epinefrin (1:1000). Pada area wajah dilakukan blok nervus (tidak dilakukan infiltrasi cairan untuk menghindari adanya magnifikasi yang dapat mengakibatkan kesalahan dalam pengukuran). ${ }^{1}$

\section{Prosedur MAFT}

\section{Pengambilan Jaringan Lemak}

Jaringan lemak diambil dari regio paha bagian medial dengan anestesi lokal lidokain $0.5 \%$ dan epinefrin 1:300.000. Stab wound insisi berukuran $2-3 \mathrm{~mm}$ dengan pisau nomer 15 untuk memasukan kanul tumpul berdiameter $1.5 \mathrm{~mm}$ sebagai larutan tumescent. Sejumlah jaringan lemak sekitar $50 \mathrm{ml}$ sesuai dengan besar kecilnya ukuran kelainan pada wajah diambil dengan spuit 60 cc tekanan negatif. (Gambar 1)

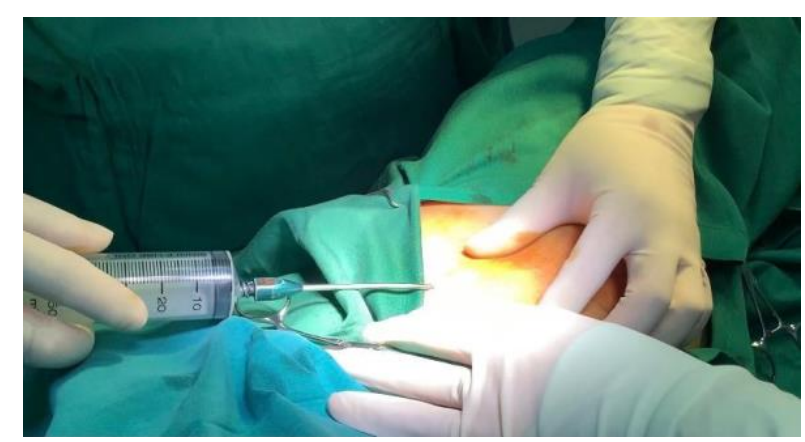

Gambar 1. Pengambilan jaringan lemak dari medial paha

\section{Pemprosesan Jaringan Lemak}

Lemak yang sudah diambil disentrifugasi dengan kecepatan 3000 rpm selama 10 menit, sehingga terpisah antara komponen biologi lemak, darah, dan plasma serta non biologi seperti minyak, darah, air, dan larutan tumescent.

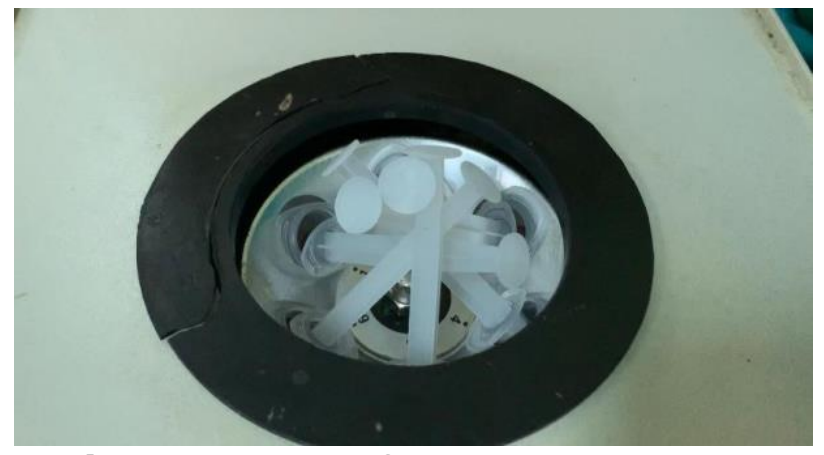

Gambar 2. Proses sentrifugasi

\section{Pentransferan Jaringan Lemak}

Akhir proses sentrifugasi, lipoaspirasi akan menjadi tiga lapisan dengan lapisan bawah adalah sel darah merah, lapisan tengah lemak, dan lapisan atas berupa minyak. Lapisan lemak dipisahkan dari lapisan lainnya untuk transplantasi. Lemak murni dipindahkan ke spuit 1cc. (Gambar 3 dan 4) 


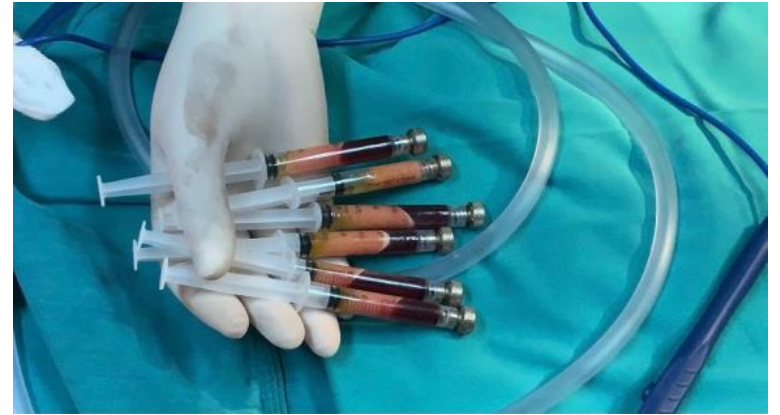

Gambar 3. Lipoaspirasi setelah sentrifugasi

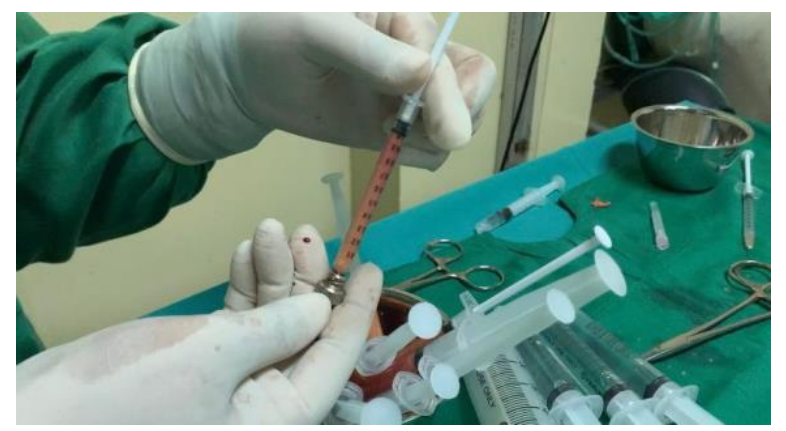

Gambar 4. Lemak murni untuk ditransplantasikan setelah lapisan sel darah merah dan minyak dihilangkan

\section{Transplantasi Jaringan Lemak}

Terlebih dahulu area resipien yang akan mendapat transfer lemak diidentifikasi dan diberi tanda, design operasi berupa lingkaran-lingkaran berbentuk seperti design peta palung bawah laut, dimana bagian yang paling dalam ditandai dengan lingkaran paling tengah (lihat gambar 5). Area resipien mendapat tindakan aseptik dan di insisi untuk memasukkan MAFT Gun. Lemak dimasukkan dengan skala tembakan 1/90 artinya setiap 1 cc lemak dalam spuit akan dibagi dalam 90 kali pengeluaran. Lemak ditransfer ke dalam pada area bawah mata sebanyak $3.5 \mathrm{cc}$, pipi $20.5 \mathrm{cc}$, dagu $3 \mathrm{cc}$, dan pelipis $1 \mathrm{cc}$. Transplantasi lemak ke dalam wajah dilakukan dalam 3 tingkat: lapisan yang lebih dalam, Deep temporal fascia (DTF) (melalui otot temporalis ke tulang temporal); Lapisan tengah, ruang areolar antara DTF ke Superficial Temporal Fascia (STF), dan lapisan superfisial, lapisan subkutan.

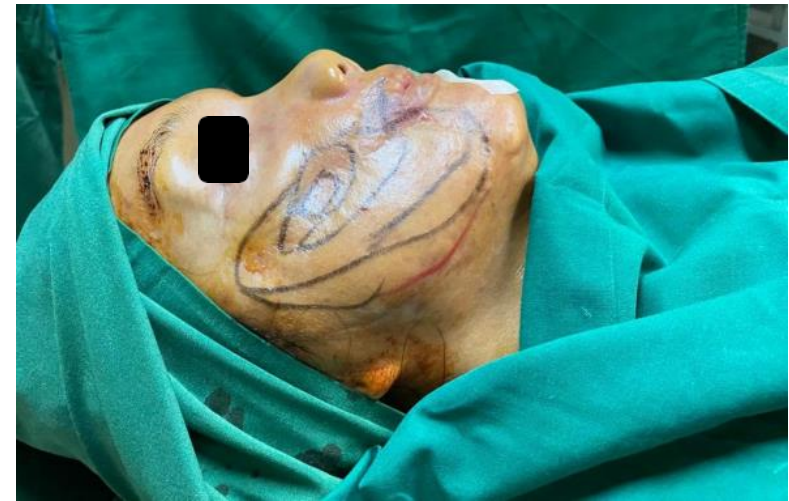

Gambar 5. Tindakan aseptik preoperasi prosedur MAFT

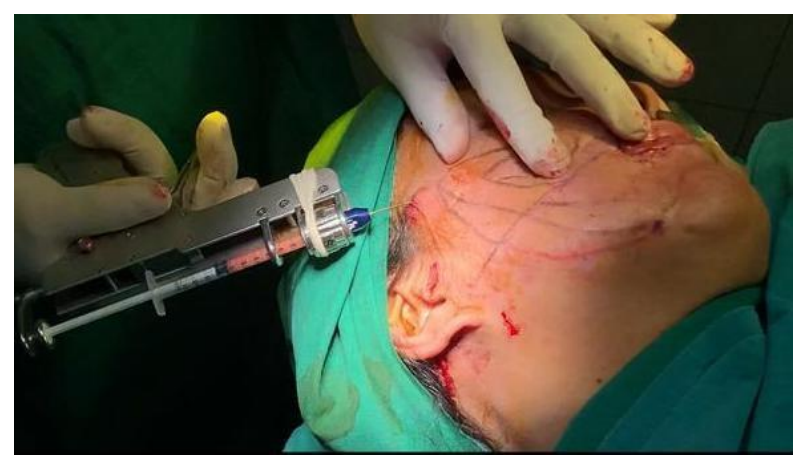

Gambar 6. Transfer lemak menggunakan MAFT gun

\section{Managemen Post MAFT}

Pasca tindakan MAFT, area resipien ditutup dengan microphore dengan tujuan untuk mengurangi gerakan untuk mencapai viabilitas yang optimal dari graft lemak yang ditanam tersebut. Untuk mencegah infeksi diberikan antibiotik oral selama 3 hari. Daerah wajah yang cekung dapat diisi dengan baik namum ada sedikit kendala disekitar parut yan belum matur, kulitnya masih kaku, sehingga belum optimal (tampak pada gambar 7).

\section{HASIL}

Komplikasi seperti infeksi, nekrosis, nodulasi, fibrosis, kalsifikasi, asimetri dan gangguan vaskular yang diamati pasca tindakan tidak tejadi. 


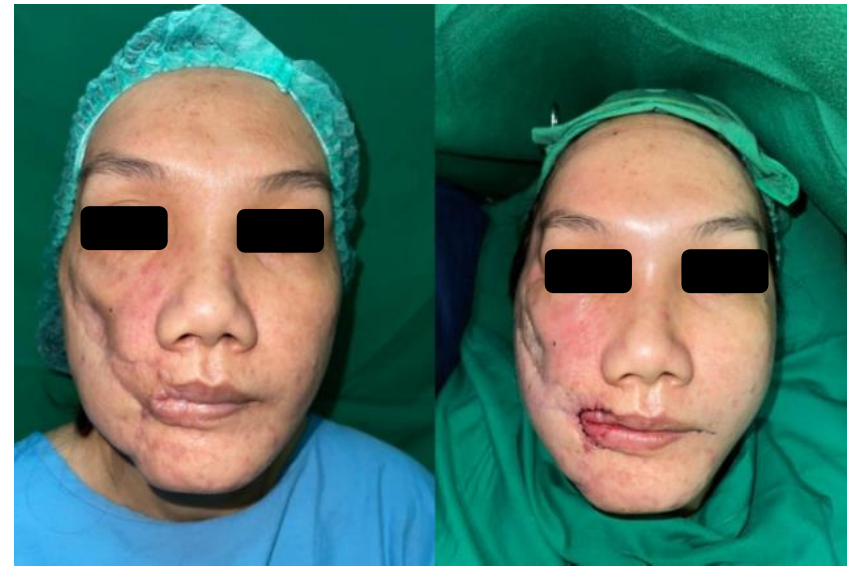

Gambar 7. Pasien dengan riwayat fraktur ZMC pasca kecelakaan lalu lintas (KLL), menjalani transfer lemak dengan MAFT dan rekontruksi komisura dengan advancement flap dan sling prolene. Pre operasi (Kiri). Pasca operasi (Kanan). Tampak parut berbentuk trapped door deformity yang sulit diangkat oleh karena masih kaku.

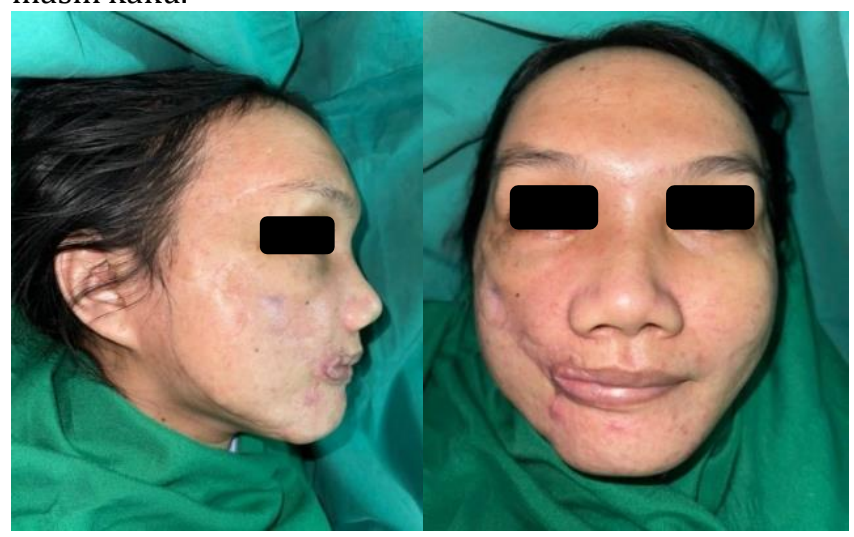

Gambar 8. Post Operasi 3 bulan tampak defek cekung sudah terisi sekitar $75 \%$ dan bagian parut berbentuk trapped door deformity sudah mulai melunak. Pasien cukup puas dan sudah siap untuk dilakukan touch up dengan memasukkan kembali MAFT.

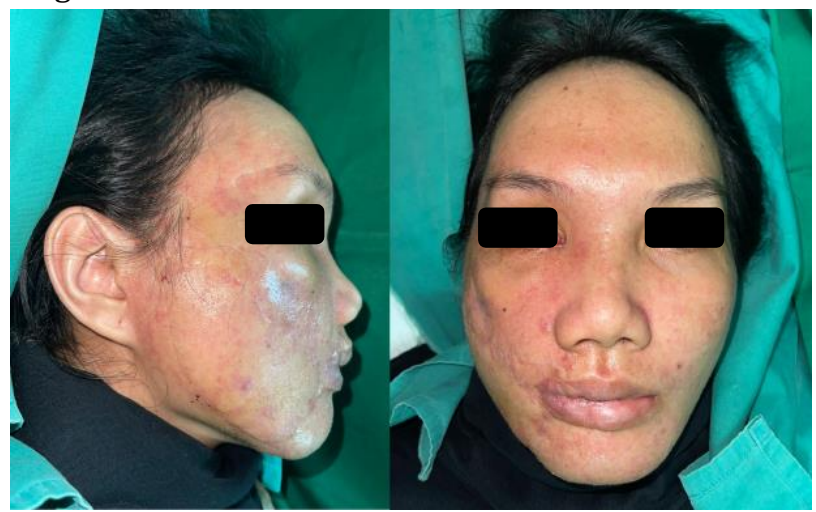

Gambar 9. 1 bulan post op kedua (operasi dilakukan 4 bulan pasca operasi pertama). Tampak wajah sudah lebih simetris. Masih terdapat bagian dimple pada malar dextra akibat scar yang membentuk trapdoor.

\section{DISKUSI}

\section{Microautologus Fat Transplantation} pada pasien ini setelah pengamatan 3 bulan menunjukkan resorpsi yang sangat minimal, pasien cukup puas walaupun diperlukan touch up berupa sejumlah kecil MAFT ulangan untuk mengisi sisa defek terutama di bagian sekitar parut yang mengalami trapped door deformity.

Menurut Peer et al. tahun 1956, melalui pengamatan histologis, lemak yang ditransfer akan mengalami resorpsi sebanyak 20 hingga $90 \%$ yaitu mengikuti hipotesis "teori kelangsungan hidup sel”. Setelah proses transfer lemak terjadi injury mekanis dan iskemia yang menginduksi nekrosis sel di perifer, sedangkan sel di central akan tetap bertahan hidup dengan inhibisi plasma dan revaskularisasi dini. Sedangkan menurut dokter Carpaneda, hanya 40\% survival rate di zona perifer sedangkan di bagian sentral mengalami nekrosis oleh karena tidak mendapatkan vaskularisasi pada proses inhibisi sel terjadi. Dengan teknik MAFT Gun butir-butir lemak ditransfer dalam jumlah yang sangat kecil dan ditempatkan pada saluran-saluran tersendiri, sehingga seluruhnya mendapatkan vaskularisasi dari resipien (seperti butir-butir tasbih, dimana setiap butir akan mendapatkan kontak yang adekuat).

Seperti kita ketahui bahwa setiap graft apapun viabilitasnya sangat bergantung kepada: ketebalan graft, kontak yang adekuat dengan resipien, vaskularisasi resipien bed, fiksasi graft yang adekuat, tidak melayang atau mengambang karena hematom, eksudat, transudat serta tidak lisis oleh karena infeksi. Berbagai teknik pengambilan jaringan lemak dan persiapan disarankan untuk mendapatkan sel adiposit dengan kelangsungan hidup yang lebih panjang. Dalam kasus digunakan MAFT Gun karena memiliki mekanisme kontrol inovatif, presisi akurat, konsisten, dan telah dipatenkan. MAFT Gun menembakkan lemak dalam volume $1 / 60,1 / 90,1 / 120,1 / 150$, $1 / 180$, dan $1 / 240$ mL. Volume yang 
ditembakkan MAFT Gun dapat dikontrol sehingga menghindari nekrosis sentral dan komplikasi lanjutan. Pelepasan paket yang besar akan mengakibatkan nodulasi dan ketidakteraturan kulit setelah transfer lemak.

Hasil dari MAFT Gun telah menunjukkan hasil ukuran parsel terkontrol yang menguntungkan secara klinis. Coleman menjelaskan bahwa area tertentu perlu mendapat volume paket tertentu. Sebagai contoh area periorbital perlu mendapat paket lemak 1/30-1/50 mL (0.020-0.033 mL) untuk mencegah nekrosis sentral.

Bagian sentral parsel lemak pada radius lebih dari $2 \mathrm{~mm}$ akan nekrosis karena difusi langsung dan gangguan inhibisi plasma 24-48 jam pasca transfer lemak. Hal ini sesuai dengan hasil dokter Carpaneda tahun 1993 yang menunjukkan hanya $40 \%$ jaringan yang bertahan pada area 1,5 $\pm 0,5 \mathrm{~mm}$ hingga batas parsel lemak. Persentase viabilitas transfer lemak dipengaruhi ketebalan dan bentuk geometris dan berbanding terbalik dengan diameter parsel. Sehingga transfer lemak dalam ukuran alikuot kecil menguntungkan dan radius yang tepat adalah 1 hingga $2 \mathrm{~mm}$. Alikuot injeksi yang ideal adalah $1 \mathrm{~mL}$ transfer lemak yaitu antara 30 hingga 240. Hal ini dijadikan sebagai dogma sentral trasplantasi lemak mikro autologous (MAFT) sesuai anjuran Lin et al. 1,7

Area donor dari berbagai regio belum ada data yang menunjukkan hasil lebih baik. Beberapa penelitian menyarankan mengambil lemak batang tubuh untuk mendapatkan sel prekusor adiposit sebagai area donor yang lebih baik. Meskipun demikian, pengalaman dalam injeksi transfer lemak dari berbagai area tubuh belum menemukan perbedaan hasil. Hasil Rohrict et al. juga menunjukkan bahwa viabilitas adiposit dari area abdomen, paha, dan tumit tidak berbeda secara signifikan. ${ }^{7}$

Microautologus Fat Transfer touch up sekunder biasa dilakukan 4 hingga 6 bulan setelah tindakan pertama MAFT bagi pasien yang menginginkan volume tambahan. Jika terjadi resorpsi jaringan lemak yang berat pasca sesi pertama MAFT, tindakan MAFT touch up sekunder juga diperlukan. ${ }^{7}$ Hanya sekitar lebih dari 50\% jaringan lemak pada sesi pertama MAFT akan teretensi dan menunjukkan hasil jangka panjang 4 bulan hingga 4 tahun. Sehingga pasien perlu mendapatkan informed consent terlebih dahulu mengenai 2 sesi atau lebih MAFT yang dibutuhkan sebelum operasi untuk mendapatkan hasil yang baik.

Manajemen pasca MAFT ditujukan untuk meminimalkan pembengkakan dan mencegah migrasi jaringan. Langkah yang biasa dilakukan adalah terapi dingin dan tekanan eksternal dengan pita elastis. ${ }^{9}$ Komplikasi pasca transfer lemak yang biasa terjadi yaitu masalah estetika akibat penempatan lemak yang terlalu banyak atau sedikit pada area tertentu yang berakibat pada ketidakteraturan. Hal tersebut dipengaruhi oleh sifat intrinsik masing-masing individu, teknik transfer yang digunakan, dan migrasi setelah transfer lemak. Kejadian komplikasi estetika ini menurun secara signifikan pada ahli bedah yang telah berpengalaman. Sedangkan komplikasi akibat pertumbuhan jaringan lemak yang berlebih jarang dilaporkan. ${ }^{10}$

\section{KESIMPULAN}

Berbagai langkah dilakukan untuk mengembalikan kontur wajah. Pasien Asia lebih tidak memilih implan atau teknik filler untuk mengembalikan simetrisitas wajah. MAFT merupakan alternatif strategi untuk mengembalikan volume scar yang depres. Walau mungkin memerlukan lebih dari 1 sesi untuk mengatasi reabsorpsi lemak. Ahli bedah plastik dengan tepat dapat mengisi volume area depresi dengan MAFT Gun dengan tembakan yang lebih presisi. Volume yang akan ditembakkan oleh MAFT Gun dapat diatur bervariasi mulai 1/60, 1/90, 1/120, $1 / 150,1 / 180$, hingga $1 / 240 \mathrm{~mL}$ untuk 
mencegah komplikasi nekrosis sentral yang berakibat morbiditas, abses, kista, nodulasi, fibrosis berat, dan kalsifikasi.

Kasus ini menunjukkan prosedur sederhana dengan teknik MAFT yang mampu mengembalikan restorasi volume area wajah. Tidak hanya memperbaiki kontur wajah tetapi juga memperbaiki tekstur kulit yang berkelanjutan. Efektivitas hingga jangka panjang lebih lanjut menunjukkan bahwa MAFT Gun dapat diandalkan untuk rekonstruksi area wajah. ${ }^{7}$ MAFT Gun mampu memperbaiki deformitas maksilofasial pasca trauma. Walau MAFT Gun telah menunjukkan hasil yang baik secara klinis tetap diperlukan studi prospektif lebih kompleks dengan kontrol radiologis jangka panjang untuk memahami sifat biologis jaringan lemak yang ditransplasikan pasca trauma dan untuk ketahanan jangka panjang. ${ }^{5}$

Transfer lemak pada area tubuh yang bergerak merupakan tantangan tersendiri oleh karena gerakan tentu saja akan mempengaruhi kontak yang adekuat antara kontak dengan resipien bed. Diperlukan pemahaman yang baik kepada pasien bagaimana pasien tersebut dapat menghindari gerakan yang berlebihan pasca operasi.

Pada kasus ini pasien mengalami skin loose dan lip loose terutama pada sisi kanan, sehingga timbul defek kontraktur komisura kanan dilakukan advancement flap commisura dan dipertahankan dengan static sling (benang polypropylane 2.0) dari komisura ke arah mastoid. Tindakan ini merupakan prosedur sementara sambil mengharapkan berfungsinya otot-otot wajah sisi kanan yang mengalami atrofi. Diperlukan evaluasi jangka panjang untuk melihat proses yang terjadi.

\section{DAFTAR PUSTAKA}

1. Lee SS, Huang YH, Lin TY, Chou CK, Takahashi H, Lai CS, et al. Long-Term outcome of microautologous fat transplantation to correct temporal depression. J Craniofac Surg.
2017;28(3):629-34.

2. Chou CK, Lee SS, Lin TY, Huang YH, Takahashi H, Lai CS, et al. Micro-autologous Fat Transplantation (MAFT) for Forehead Volumizing and Contouring. Aesthetic Plast Surg. 2017;41(4):845-55.

3. Agrawal KS, Bachhav M, Naik CS, Tanwar H, Sankhe SS. Autologous Fat Transfer for Esthetic Contouring of Face in Posttraumatic Nonfunctional Maxillofacial Deformities. Craniomaxillofac Trauma Reconstr. 2016 Jun;9(2):113-20.

4. Ji SY, Kim SS, Kim MH, Yang WS. Surgical Methods of Zygomaticomaxillary Complex Fracture. Arch Craniofacial Surg. 2016;17(4):206.

5. He D, Li Z, Shi W, Sun Y, Zhu H, Lin M, Shen G FX. Orbitozygomatic fractures with enophthalmos: analysis of 64 cases treated late. J Oral Maxillofac Surg. 2012;70(3):56276.

6. Drochioi C, Sulea D, Marius D. Correction of Sequelae Following Orbito-Zygomatic Fractures. Romanian Journal of Oral Rehabilitation. 2018;10(4):198-206.

7. Arcuri F, Brucoli M, Baragiotta N, Stellin L, Giarda M, Benech A. The Role of Fat Grafting in the Treatment of Posttraumatic Maxillofacial Deformities. Craniomaxillofac Trauma Reconstr. 2013 Jun;6(2):121-5.

8. Krastev TK, Beugels J, Hommes J, Piatkowski A, Mathijssen I, Van Der Hulst R. Efficacy and safety of autologous fat transfer in facial reconstructive surgery a systematic review and meta-analysis. JAMA Facial Plast Surg. 2018;20(5):351-60.

9. Guisantes E, Fontdevila J, Rodríguez G. Autologous fat grafting for correction of unaesthetic scars. Ann Plast Surg. 2012;69(5):550-4.

10. Coleman SR. Structural fat grafting: More than a permanent filler. Plast Reconstr Surg. 2006;118(3 SUPPL.):108-20. 